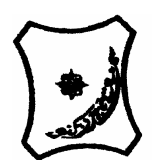

Bayero Journal of Pure and Applied Sciences, 9(2): 166 - 173

Received: June, 2016

Accepted: September, 2016

ISSN $2006-6996$

\title{
ISOLATION AND IDENTIFICATION OF FUNGI RESPONSIBLE FOR LEAF SPOTS DISEASE OF MANGO (Mangifera indica LINNEAUS) IN SOKOTO STATE, NIGERIA
}

\author{
Zainab, M. B. ${ }^{1}$ and Shinkafi, S. A. ${ }^{2}$ \\ Department of Biological Sciences Usmanu Danfodiyo University Sokoto, Nigeria ${ }^{1}$ \\ Department of Biological Sciences Federal University Gusau, Zamfara State, Nigeria ${ }^{2}$ \\ Corresponding author:saadatushinkafi@rocketmail.com
}

\begin{abstract}
A survey was carried out to investigate the incidence of fungal leaf spots disease of mango (Mangifera indica) in Sokoto metropolis using random sampling methods. Field survey was carried out in six mango growing areas; Arkilla, Dambuwa, Gagi, Illela, More and permanent site of the Usmanu Danfodiyo University, Sokoto. Diseased plant leaves were identified using disease symptoms. A total of 125 healthy and diseased leaves were collected using detached leaf technique. The diseased plant leaves were taken to the laboratory for culture, isolation, and identification of pathogens. Plant disease incidence was determined using disease index and severity scale of 0-4 rating. Eleven fungal pathogens were isolated and identified. These included; Alternaria longipes, Aspergillus fumigatus, Aspergillus niger, Colletotrichum gloesporioides, Fusarium oxysporum, Fusarium mangifera, Pestalotiopsis mangiferae, Phoma mangiferae, Phomopsis mangiferae, Pseudofusicoccum spp. and Rhizopus oryzae. The incidence of leaf blight was high in Usmanu Danfodiyo University, Sokoto with percentage frequency of $(56.75 \%)$, followed by Dambuwa (45.50\%), More (44.48\%), Illela (37.00\%), Gagi (34.15\%) and Arkilla (31.65\%). Leaf spots intensity was more influenced by environmental conditions and cultural practices rather than climatic factors in the areas. Also, programs aimed at enlightening the farmers on proper cultural practices and boosting mango yield and reducing pathogen invasion are recommended.
\end{abstract}

Keywords: Incidence, Fungi, Leaf spot, disease, Mango, Sokoto.

\section{INTRODUCTION}

Mango (Mangifera indica), locally known as Mangoro (Hausa), Mangolo (Igbo) and Mangoro (Yoruba) in Nigeria is an erect, branched, medium to large-sized tree. The leaves are alternately arranged, evergreen or nearly evergreen (Muhammad and Amusa, 2005). It has a wide crown and inflorescence with numerous flowers (Ugese et al., 2012; Shri, 2013). The tree is cultivated in many tropical and sub tropical regions of the world. Mango fruits vary in shape, size, colour, texture and flavor (Nelson, 2008). Mango is known worldwide as "king of fruits". It belongs to the genus mangifera consisting of numerous species of tropical fruiting trees in the flowering plant family Anacardiaceae. It is a large branched, perennial tree, which attains great heights with symmetrical rounded canopy, approximately 30-40 feet tall. Flowers appear in large terminal inflorescence producing fruits. The skin of the fruit may be green, yellow, or red, depending upon the variety of the fruit (Nelson, 2008; Fowomola, 2009; Shri, 2013).The name 'Mango' was derived from Tamil word 'mangkay' or 'man-gay' (Shri, 2013; Martins, 2014). The tree is native to Asia particularly eastern India, Burma, and the Andaman Islands where it spread to the East Africa in the $10^{\text {th }}$ century. The Portuguese introduced it to West Africa in the $16^{\text {th }}$ century (Morton, 1987). Mango came to Nigeria in the $20^{\text {th }}$ century through itinerant merchant missionaries and colonialist and is currently the integral part of indigenous cropping system (Ugese et al., 2012). The guinea and Sudan zones of Nigeria are credited with producing greater percentage of the fruit in the country. Earlier studies indicated that Agricultural Research Institute in Zaria was the centre where improved mangoes varieties were obtained (Avav and Uza, 2002). Mangoes are grown in eightyfive countries worldwide. Sixty-three of such countries provided more than 1000 metric tons in 1999. Developing countries account for about $98 \%$ of the total world production (Yusuf and Salau, 2007). Despite lack of encouragement to large scale production of tropical fruits, Nigeria occupies $8^{\text {th }}$ position in world ranking of mango producing countries as at 2002. This suggests the potential of tropical fruits in the country. Sokoto state occupies $10^{\text {th }}$ position among the main mango producing states in the country which included Jigawa, Plateau, Yobe, Kebbi, Niger, kaduna, Kano, Bauchi, Adamawa, Taraba, and FCT Abuja (Yusuf and Salau, 2007; FAOSTAT, 2007).

Mango tree vegetation in Sokoto metropolis is under threat by unidentified pathogens. Diseases has rendered its production non attractive to both farmers and home gardeners in the region. So far many works were made by researchers on mango fruits collected from different parts of Sokoto metropolis, but little or no attention is paid to its foliar diseases. 
Most of the research carried out on pest and diseases associated with mango in Nigeria were mainly concentrated/limited to humid regions; the southern part of the country with little or no work done in the MATERIALS AND METHODS

\section{Study Area}

Sokoto State is within the Sudan savanna zone. It is located between latitudes $13^{\circ} .35^{\prime} \mathrm{N}$ to $14 .^{\circ} 0^{\prime} \mathrm{N}$ and longitudes $4^{0} \mathrm{E}$ to $6^{0} \mathrm{E} 40^{\prime \prime}$. It has the total population of 3,696,999 million (NPC, 2006). The state has borders with the Niger Republic to the north, Zamfara State to the east, and Kebbi State to the south. The research was conducted at Usmanu Danfodiyo University permanent site, Arkilla, Dambuwa, Gagi, Illela and More all within Sokoto metropolis. A Purposive and randomized sampling methods of Okigbo and Osuinde (2003) were used in the survey and isolation of leaf pathogens. Survey of mango tree diseases were carried out at the Usmanu Danfodiyo Collection of Diseased Mango Samples

Diseased samples were collected into closed paper envelops and not plastic bags to avoid creating a micro climate condition for the specimen according to Delhove et al. (2013). Diseased leaves collected were sorted into envelops according to different varieties as identified by the local farmers. The envelopes were identified (i.e., numbered serially 1-25) and the varieties were also stated on each envelop. A minimum of four mango varieties were obtained from each location with the exception of More area (along Assessment of Incidence and Severity of Mangifera indica in the study area.

A systemic field survey of foliar disease of mango was carried out in the six selected mango-growing areas (Usmanu Danfodiyo University permanent site, Arkilla, Dambuwa, Gagi, illela and More) to determine foliar fungal disease frequency of occurrence and severity. Following Awa et al. (2012) and Abubakar (2009) methods with slight modification, twenty (20) mango trees in each sampling location were randomly selected. On each tree, five on-tree mango leaves were plucked, examined, and scored. Leaf spots were assessed by modifying the standards that has been in used for the assessment of leaf anthracnose of mango proposed by Awa et al. (2012). Scale 0 to 4 was used instead of 1 to 5 where scale 0 represents no leaf lesions/spots 1 represents 1 to 3 lesions, 2 represents 4 to 6 lesions, 3 represents 7 to 15 lesions and 4 where more than 70 per cent of leaf surface is covered with lesions. Disease incidence (percentage of diseased leaves), and disease severity (percentage of area affected on the leaf on average) were then obtained by the following formula:

1. No disease symptoms on leaves (rated zero) .

2. $1-25 \%$ of leaf area covered with spots (scored as 1) .

3. $26-50 \%$ of leaf area covered with spots (scored as 2).

4. $51-75 \%$ of leaf area covered with spots (scored as 3).

5. $76 \%$ or more (scored as 4 ).

Disease Incidence (D I \%) $=\mathrm{x} / \mathrm{N} \times 100$

OR

D.I $(\%)=\underline{\text { No. of infected trees }}$ northern parts. Anthracnose is presently the most important field and post harvest disease of mango widely distributed in all mango-growing regions of the world (Okigbo and Osuinde, 2003; Stovolt, 2004; Nelson, 2008; Uliwa, 2008; Awa et al., 2012).

University permanent site, Arkilla, Dambuwa, Gagi, More and Illela all within Sokoto metropolis. To determine the frequency of occurrence of diseased mango trees at the study area, at each site, 20 mango trees were randomly selected and inspected. The frequency of occurrence was taken as the number of mango trees affected by the disease expressed as percentage of the total number of mango trees at a location. A visual assessment technique was used with which many plantations were evaluated in a relatively short time as put forward by Okigbo and Osuinde, (2003). Both healthy and diseased leaves were collected randomly without favour for the disease assessment.

\section{Sample collection}

Tashan illela /bakin gada) where five varieties were collected. In each envelop, five leaves were randomly plucked and identified (i.e. numbered serially 1-5 and scored/rated based on appearance of spots/lesions on leaf) using a masking tape. A total of 125 leaves were collected from the six locations and were taken to Usmanu Danfodiyo University of Sokoto Herberium for verification of samples varieties then later to Mycology laboratory of same institution for isolation and identification of the fungal pathogen(s) Delhoveetal. (2013).

Total number (healthy and infected) trees assessed

$\mathrm{x} 100$

Disease Severity $(\mathrm{D} \mathrm{S} \%)=\Sigma(\mathrm{a}+\mathrm{b}) / \mathrm{N} . \mathrm{Z} \times 100$ (Awa et al., 2012)

OR

D.S $(\%)=$ Sum of all diseased leaves ratings or scores

Total number of leaves examined $\mathrm{x}$ maximum score $\mathrm{X} 100$

Where;

$\Sigma(a+b)=$ Sum of infected/diseased leaves and their corresponding score scale.

$N=$ Total number of sampled trees

$Z=$ Highest/maximum score scale/rating

$X=$ Number of infected/diseased trees (Abubakar, 2009; Awa et al., 2012)

\section{Isolation of fungal Pathogens}

At the laboratory, all the eight varieties of mango obtained from the field were sorted separately. Isolation was carried out according to variety and location obtained. Leaves samples collected from Dambuwa and Gagi were not isolated because the varieties obtained from these locations are well represented in all the major mango growing regions surveyed in this research. Leaves with highest score scale from each variety were used for inoculation. Two centimetres of the infected mango leaf tissue were excised with a sterilized razor blade at the point of progression of disease symptom; then surface sterilized by dipping into 70 per cent ethanol solution for 2 minutes. The tissues were then rinsed in three changes of sterilized distilled water and were dropped on sterile paper towels, 
BAJOPAS Volume 9 Number 2 December, 2016

allowed to dry before plating them onto PDA (potato dextrose agar) in Petri dishes. A total of 17 petri dishes of PDA media were plated for mango leaf tissue (i.e. the five varieties obtained from More, four varieties each from UDUS permanent site, Arkilla and Illela respectively). These were incubated for 6 days at room temperature $\left(25-28{ }^{\circ} \mathrm{C}\right)$ under light to enhance fungal growth following Okigbo and Osuinde (2003) .

\section{Purification}

After some days, the plates were inspected to observe the growth of pathogens on the media. Some young mycelium emerging from the tissues were sub cultured on fresh PDA media with the help of a sterile loop to obtain pure isolates of the pathogens. They are checked and transferred on to new PDA media weekly and kept at room temperature $\left(21-25{ }^{\circ} \mathrm{C}\right)$ to maintain pure cultures at all times for correct identification of fungal pathogens. Isolated colonies were sub-cultured into fresh plates until pure cultures were obtained. Pure cultures obtained were identified from each variety by visual examinations and viewing under electronic microscopes.

\section{Identification of foliar fungal pathogens}

After three consecutive times of purifying the plates following the method of Saeed (2012). The Plates were inspected again for growth and purity. Some of the pure cultures obtained, on Potato dextrose agar had colonies that were whitish to dark grey with thick to sparse lawns of aerial mycelium when viewed from the top of Petri dishes similar to Awa et al. (2012) description and were greenish to orange or dark brown centre bordered by creamy surrounding when viewed from the reverse side of the Petri dish. When viewed under the microscope, conidia were observed to be hyaline; single celled and cylindrical with obtuse ends. The fungus was, identified to be Colletotrichum gloeosporioides. A total of 48 pure cultures were obtained out of which $C$. gloesporiodes had the highest occurrence of 12 plates. Some plates exhibited similarities in morphological growth and were therefore divided into groups. Eleven different groups with similar growth morphologies of isolates within each group were identified and three distinct and morphologically different from any isolate were also identified as Aspergillus fumigatus, Pestalotiopsis mangiferae and Phomopsis mangiferae .

A maximum of three pure isolates that have similar morphology were carefully selected from each group of eleven isolates and assumed that they were all the same. They were grouped according to the growth shown (colony characteristics). Purification was done for the various groups to ensure pure isolates were obtained at all the times. Temporary slides from each group of mango leaf isolates were made after carefully selecting the purest and observed under light/electronic microscope. Some unidentified spores were observed to be similar to Pseudofusicoccum spp. and were identified as such. A total of eleven pathogens (Alternaria longipes, Aspergillus fumigatus, Aspergillus niger, Colletotrichum gloesporioides, Fusarium oxysporum, Fusarium mangifera Pestalotiopsis mangiferae, Phoma mangiferae, Phomopsis mangiferae, Pseudofusicoccum spp., and Rhizopus oryzae) were identified and were then described and classified based on conidia and colony morphology as described by Barnett and Hunter (1998), Ellis and Hermanis (2003), Palvic et al. (2008), Guo-yin et al. 2013), Nyongesa et al. (2015), and Gagkaeva (2008). Stock cultures of all the isolates were maintained on PDA slopes in McCartney bottles at $4^{\circ} \mathrm{C}$ in the dark.

\section{RESULTS}

From the field survey carried out, More area had the largest number of mango tree population with this research estimating the figure at 1,800 (table 1 ). There are climatic and socio economic factors explaining this reality. The trees are planted on the northern bank of River Rima, which supplies moisture for the most part of the year. On the southern bank of the river lies the city of Sokoto, a sprawling urban centre providing a huge demand for the mango fruits. As further depicted in figure 1, Usmanu Danfodiyo University, Sokoto (UDUS) is the environment home to the second largest concentration of mango trees, with this research estimating a total of 580 mango trees in the area (Table 1). Next in importance is Illela where an estimated total of 280 mango trees thrive (Table 1 ). The remaining areas of Arkilla, Dambuwa and Gagi are home to an estimated total of 110,65 and 38 trees respectively.

Table 2, shows the disease incidence by location. From the table, it is evident that judging by the two measures of leaf infection (i.e. leaf score and disease severity) UDUS ( $56.75 \%)$ had the highest, followed by Dambuwa (45.50\%), More (44.48\%), Illela (37.00\%), Gagi $(34.15 \%)$ and Arkilla $(31.65 \%)$ in that order. The bar graph shown in Figure 1 is also used to support this fact.

Table 3 indicated the number of Fungi isolated from (8) eight different mango varieties and locations.

Plate I and II shows Five (5) days old $C$. gloeosporioides colony on Potato Dextrose Agar plate isolated from cultivar Binta siga of UDUS and ten (10) days old $C$. gloesporioides colony on PDA plate isolated from cultivar Binta siga of UDUS. The different isolates selected produced similar morphological and cultural growth for the different mango varieties. The morphological and cultural characters (including colours of the colony and mycelia growth) on PDA were observed after a period of 7 days at room temperature of $21-25^{\circ} \mathrm{C}$. With similarity to description made by Saeed (2012), most of the mango varieties isolated on PDA plates initially develop grayish to whitish zonate colonies in which some later develops colour and acervuli. The colour gradually becomes darker as fungi grow old with time Plate III indicated the Surface, reverse, and morphology of conidia (under light microscope) of $C$. gloeosporiodes isolated from mango leaf (. Binta siga) from More area. From the experiment conducted, 12 isolates out of 48 were identified to be $C$. gloesporioides. Base on description by Barnett and Hunter (1998) colonies on PDA were whitish to dark grey with thick to sparse lawns of aerial mycelium when viewed from the top of Petri dishes and were greenish to orange or dark brown centre bordered by creamy surrounding when viewed from the reverse side of the Petri dish. When viewed under the microscope, conidia were observed to be hyaline; single celled and cylindrical with obtuse ends 
BAJOPAS Volume 9 Number 2 December, 2016

Table 1: Mango tree population by location in Sokoto metropolis

\begin{tabular}{lcc}
\hline Location & Estimated Mango tree population & Estimated infected Mango Trees \\
\hline Arkilla & 110 & 25 \\
Dambuwa & 65 & 16 \\
Gagi & 38 & 11 \\
Illela & 224 & 27 \\
More & 1800 & 182 \\
UDUS & 580 & 72 \\
\hline
\end{tabular}

Key: UDUS = Usmanu Danfodiyo University Sokoto

Table 2: Disease Incidence by sampling size

\begin{tabular}{|c|c|c|c|c|c|c|c|}
\hline Location & No spot & $1-25$ & $26-50$ & $51-75$ & $75-100$ & $\begin{array}{l}\text { Leaf } \\
\text { Score }\end{array}$ & $\begin{array}{l}\text { Disease } \\
\text { Severity } \\
(\%)\end{array}$ \\
\hline Arkilla & 4 & 6 & 5 & 3 & 2 & 1.65 & 31.65 \\
\hline Dambuwa & 0 & 2 & 4 & 3 & 1 & 2.30 & 45.50 \\
\hline Gagi & 4 & 4 & 6 & 5 & 1 & 1.75 & 34.15 \\
\hline Illela & 10 & 4 & 6 & 2 & 8 & 1.80 & 37.00 \\
\hline More & 1 & 6 & 6 & 10 & 2 & 2.24 & 44.48 \\
\hline UDUS & 0 & 3 & 5 & 6 & 6 & 2.75 & 56.75 \\
\hline All Locations & 19 & 25 & 32 & 29 & 20 & 2.05 & 41.02 \\
\hline
\end{tabular}

Key: UDUS = Usmanu Danfodiyo University Sokoto

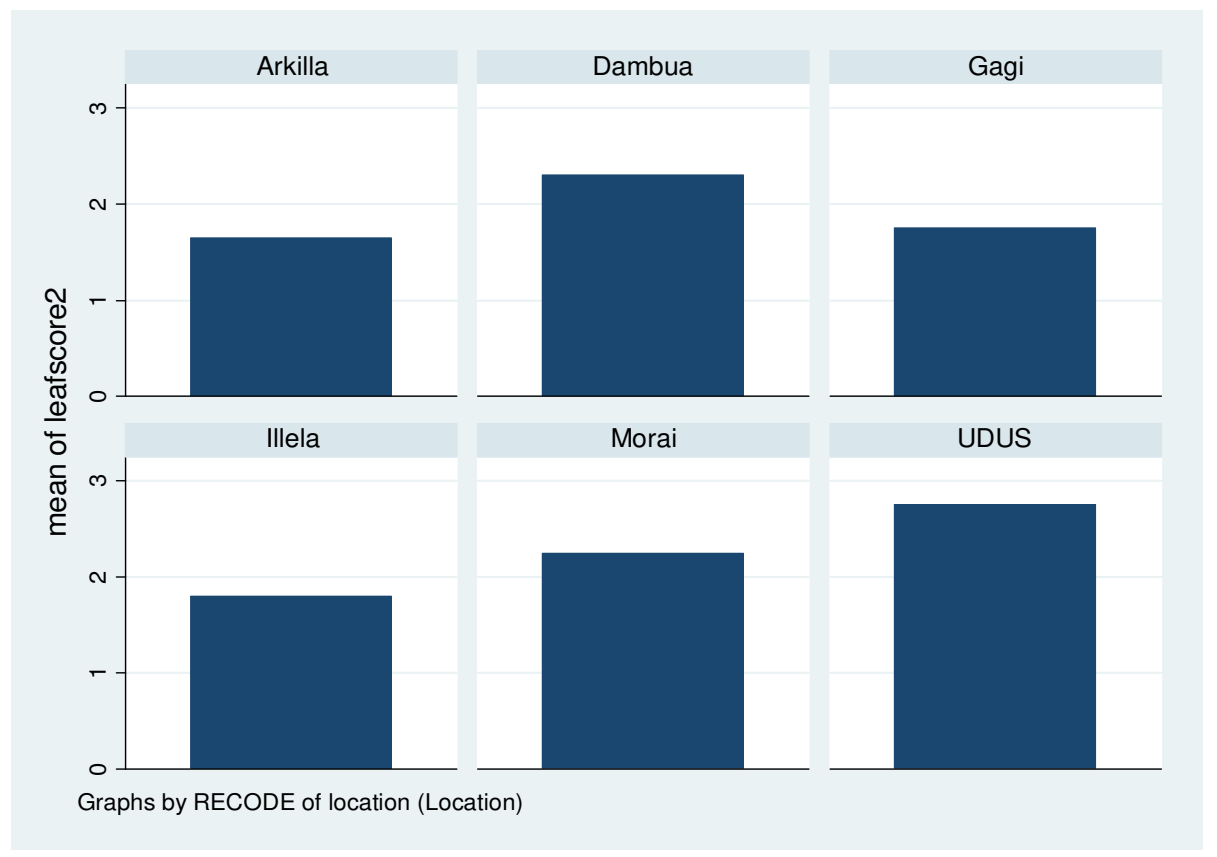

Figure 1: Mean Disease Severity by sampling size. 
Table 3: Fungi isolated on the basis of mango varieties and locations

\begin{tabular}{|c|c|c|c|}
\hline Fungal isolates & Mango variety & Location & $\begin{array}{l}\text { Number } \\
\text { Petridishes }\end{array}$ \\
\hline \multirow[t]{5}{*}{ Alternaria longipes } & Babbar Turmi & Illela & 2 \\
\hline & BaDDar I UrmI & 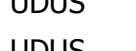 & \\
\hline & Binta siga & UDUS & 1 \\
\hline & Binta siga & More & 1 \\
\hline & Dankamaru & UDUS & 1 \\
\hline Aspergillus fumigatus & Dankamaru & Illela & 1 \\
\hline \multirow[t]{3}{*}{ Aspergillus niger } & Binta siga & UDUS & 1 \\
\hline & Mai bindiga & More & 2 \\
\hline & Peter & More & 2 \\
\hline \multirow[t]{6}{*}{ Colletotrichumgloesporioides } & Bakin aku & Arkilla & 2 \\
\hline & Binta siga & Illela & 1 \\
\hline & Binta siga & UDUS & 2 \\
\hline & Dan dogo & More & 2 \\
\hline & Dankamaru & UDUS & 3 \\
\hline & Dankamaru & Illela & 2 \\
\hline Fusarium mangiferae & Binta siga & UDUS & 2 \\
\hline \multirow[t]{3}{*}{ Fusarium oxysporum } & Binta siga & More & 1 \\
\hline & Mai bindiga & More & 3 \\
\hline & Peter & More & 2 \\
\hline Pestalotiopsis mangiferae & Dankamaru & More & 1 \\
\hline \multirow[t]{3}{*}{ Phoma mangiferae } & Bakin aku & UDUS & 1 \\
\hline & Binta siga & More & 1 \\
\hline & Binta siga & Illela & 5 \\
\hline Phomopsis mangiferae & Binta siga & Illela & 1 \\
\hline Pseudofusicoccum sp & Binta siga & More & 3 \\
\hline Rhizopus oryzae & Dankamaru & Illela & 4 \\
\hline & & & 48 \\
\hline
\end{tabular}

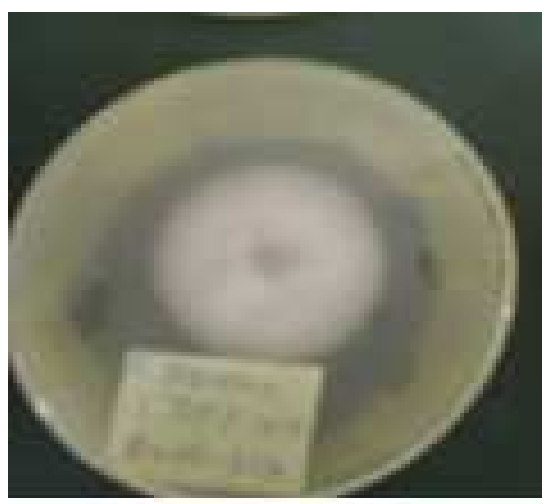

Plate I: Five (5) days old C. gloeosporioides colony on PDA plate isolated from cultivar Binta siga of UDUS. 


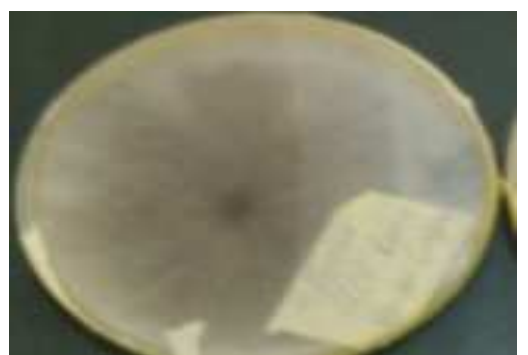

Plate II: Ten (10) days old C. gloesporioides colony on PDA plate isolated from cultivar Binta siga of UDUS.
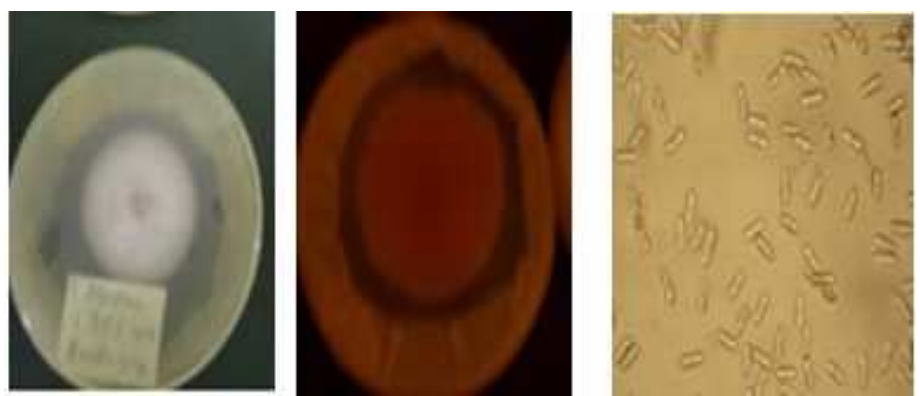

Plate III. Surface, reverse, and morphology of conidia (under light microscope) of C. gloeosporiodes on PDA, isolated from mango leaf (cv. Binta siga) from more.

\section{DISCUSSION}

pathogens from south-eastern part of Nigeria among

Many studies were made so far on mango fruits collectedwhich are Macrophoma mangiferae and Pestalotiopsis from different parts of Sokoto metropolis, Nigeria at largemangiferae. Diedhiou et al. (2007) also identified including other tropical regions of the world where mangoPhoma mangiferae, Alternaria sp. and Aspergillus is grown. However, most of the pathogens isolated fromiger, among other pathogens as major causes brown this study are known to infest mango fruits. The results oend black spots on mango leaves. Agrios (2005), this study however revealed some interesting facts as sameurther reported that Phoma spp. cause numerous pathogens could also infest not only fruits but also itsliseases of vegetables and other annual plants. They leaves. are often present with other weak pathogens.

According to Agrios (2005), many pathogens, especiallyfusarium mangifera was isolated only from UDUS foliar (leaf) pathogens, need a film of water on the plant tфalong Kofar Mata). The place is usually dry most time begin growth, penetrate the host, and establish infectionof the year. Iqbal et al. (2008) reported that Fusarium This is why wet or humid weather is so important in themangifera is one among many fungi responsible for development of many fungal and bacterial diseases. Thఱnango malformation diseases resulting from various regular water supply from the River Rima to the mangळiotic and abiotic stresses. Malformation is the most trees at More village seems to explain the observedmportant malady causing colossal losses every year. susceptibility of the trees in that location to theseAccording to Agrios (2005), Fusarium generally causes pathogens. Stovolt (2004) similarly stated that wetascular wilts of vegetables and flowers, herbaceous conditions favour most diseases especially anthracnos甲erennial ornamentals and plantation crops. Most of disease.

Mango anthracnose disesease caused by Colletotrichum gloesporioides had the highest occurrence (Table 1) from the research. $C$. gloesporioides were isolated from all the areas surveyed. Therefore, this could explain why Okigbo and Osuinde (2003), Stovolt (2004), Uliwa (2008), Nelson (2008), and Awa et al. (2012), unanimously agreed that anthracnose is presently the most important field and post harvest disease of mango widely distributed in all mango-growing regions of the world.

Phoma mangiferae is the second largest reoccurring pathogen (isolated from Illela, More and UDUS). Saeed (2012) reported that Phoma sp. causes phoma blight in mango and can only be observed on matured or old leaves because it is a weak pathogen that invades stress plants. It causes spot that are fully developed and are characterized by dark margin and dull necrotic centre. Okigbo and Osuinde (2003), similarly identified and isolated some leaf spot the wilt causing Fusarium fungi belongs to the species Fusarium oxysporum. All vascular wilts have certain characteristics in common. The leaves of infected plants or of parts of infected plants lose turgidity, become flaccid and lighter green to greenish yellow, droop, and finally wilt, turn yellow, then brown, and die. Wilted leaves may be flat or curled. Young, tender shoots also wilt and die. Dhoro (2010) similarly reported that $F$. oxysporum, are among the most devastating plant diseases in the world.

Phomopsis diseases appear primarily as cankers that kill twigs and small branches of ornamental shrubs and trees (Agrios, 2005; Diedhiou et al., 2007). In a similar study by Saeed (2012), Phomopsis sp. (of the family Diapothaceae) have been associated to also cause leaf spots, cankers, root rots, fruit rots, diebacks, blights, decay and wilts on a broad range of plant hosts including a number of economically important Phomopsis mangifera is linked to also cause stem-end rot and dieback in mango. 
Pestalotiopsis mangiferae is reported to cause gray leaf spot in mangoes (Saeed 2012). This conforms to the report of Kamil et al. (2012) and Okigbo and Osuinde (2003).

Although there are no previous reports of Pseudofusicoccum sp. and Alternaria longipes and Rhizopus oryzae isolations from mango, however, it has been isolated and identified from this study. Alternaria longipes was identified and isolated by Guoyin et al. (2013) to be the fungal pathogen causing leaf spot on Atractylodes macrocephala the reason according to their findings being that both plant pathogenic and saprophytic species of Alternaria may cause leaf spot and blight on numerous plant taxa including vegetables, fruit trees and ornamentals. Therefore from this study, we can establish that Pseudofusicoccum sp. and Alternaria longipes and Rhizopus oryzae could also be the cause of fungal leaf spot on mango.

Aspergillus niger was confirmed by various studies such as Nyongesa et al. (2015), Awa et al. (2012), Diedhiou et al. (2007), Khaskheli et al. (2008) among

\section{REFERENCES}

Abubakar, M. N. (2009). Occurrence, Identification, and Pathogenicity of Diseases on Jatropha curcas in some North-western states of Nigeria. A Dissertation Submitted to the Department of Biological sc. Usmanu Danfodiyo University Sokoto, Nigeria. Unpublished.

Agrios, G.N (2005). Plant Pathology. Fifth (5th) edition. Pp. 27-557.

Avav, T. and Uza, D. V. (2002). Agriculture. In: Pigeonniere, A. L. (Ed) Africa Atlases: Nigeria, Les Editions ]. A., Paris, pp 92-95.

Awa, O. C., Samuel, O., Oworu, O. O. and Sosanya, O. (2012). First Report of Fruit 4 Anthracnose in Mango caused by $\mathrm{C}$. gloeosporioides in Southtern Nigeria. International Journal of Scientific \& Technology Research 1: 30-34.

Barnett, H.L. and Hunter, B.B. (1998). Illustrated Genera of Imperfect Fungi. APS Press Pp.163-193.

Delhove, R. and Vannière. (2013). New pests and invasive diseases. Mango Bacterial Disease. Avaialable on www.coleacp.org/pip

Dhoro, M. (2010). Identification and Differentiation of Fusarium Species using Selected Molecular Methods. Master of Philosophy Research Paper. Submitted to the Department of BiochemistryUniversity of Zimbabwe. Pp 574.

Diedhiou, P. M., Mbaye, N. Dramé, A. and Samb, P. I. (2007) .Alteration of post harvest diseases of mango Mangifera indica through production practices and climatic factors. African Journal of Biotechnology Vol. 6 (9), pp. 1087-1094

Ellis, D. and Hermanis, R. (2003). Rhizopus oryzae. Geraldine Keminski medical. Available on : www.doctorfungus.org@2005. others implicated these fungi species to be the fungi responsible for postharvest diseases of mango associated with fruit rotting during ripening. Mango leaves could also be affected as the dusty charcoal spores of the black mold which could easily be dispersed by air from infected fruits.

\section{CONCLUSION}

Anthracnose was found prevalent in all the mangogrowing areas surveyed, the occurrence and severity was more influenced by environmental conditions and cultural practices rather than climatic factors in the areas. Fruit yield drastically reduced in areas with highest anthracnose disease occurrence and severity, an indication that anthracnose disease phenomenon has negative correlation with fruit yield. This phenomenon was largely influenced by environmental conditions and cultural practices. A combination of resistant varieties, soil fumigation, application of fungicides and so on may reduce but do not eliminate the disease.

FAOSTAT. (2007). FAO Statistics, Food and Agriculture Organization of the United Nations, Rome, Italy. Available on: http://faostat.fao.org/.

Fowomola, M. A. (2009). Some nutrients and antinutrients contents of mango (Magnifera indica) seed. African Journal of Food Science (8): $472-476$.

Gagkaeva, T. (2008). Introduction to Fusarium taxonomy. Laboratory of Mycology and Phytopathology. All-Russian Institute of Plant Protection St. Petersburg, Russia. Pp 123 130.

Guo-yin, T. Y. Z., Yuan, Z. and Zhang, S. (2013) :Morphological, molecular and pathogenic characterization of Alternaria longipes, the fungal pathogen causing leaf spot on Atractylodes macrocephala. African Journal of Microbiology Research. 7 (21): 25892595.

Iqbal, Z., Ahmad, K., Zafar, I. K., Ehsan, E. V., Muhammad, M. and Muhammad A. P (2008). Variability Among Isolates of Fusarium mangefarae Associated Malformation Diseases of Mango. Pak. J. Bot., 40 (1): 445452.

Kamil, D., Prameeela D.T.,Mathur, N., Singh, O.P., Pandey P., Parabhakaran N., and Patil V. (2012). Addition of New Species of Pestalotiopsis to the Fungal Diversity in India. J mycopathol, Res, 50 (2). 185-191.

Khaskheli ,M. I., Pathan, M.A., Jiskani, M.M., Wagan, K.H., Manzoor, Soomro, H. and Poussio, G.B. (2007). First Record of Fusarium nivale (FR) CES. Associated with Mango Malformation Disease (MMD) in Pakistan. Pakistan-African Journal of Biotechnology. 6 (9), pp. 1087-1094. 
Martins, A.T. (2014). How to Make Money Exporting Mango, Business ideas in Nigeria. Available on http://www.mytopbusinessideas.com/makemoneyexporting-mango

Morton, J. (1987). Fruits of the Warm Climates, Miami, Florida, 221-239Pp.

Muhammad, S. and Amusa, N.A. (2005). Important Food Crops and Medicinal Plants in North western Nigeria. Journal of Agriculture and Biological Sciences 1 (3): 254-260.

National Population Commission (2006). Map of Sokoto; N. P. C. Available on: www.nigerianmuse.com

Nelson, S.C. (2008). Mango Powdery Mildew. In: College of tropical agriculture and human resources. Department of Plant and Environmental Protection Sciences. University of Hawai'i at Manoa, Plant Disease. PD-46. Available on : www.ctahr.hawaii.edu/nelsons/mango.

Nyongesa, B.W., Okoth, S. and Ayugi, V. (2015). Identification Key for Aspergillus Species Isolated from Maize and Soil of Nandi County, Kenya. Advances in Microbiology, 5, 205-229.

Okigbo, R. N and Osuinde, M.I. (2003). Fungal Leaf Spot Diseases of Mango (Mangifera indica L.) in Southeastern Nigeria and Biological Control with Bacillus subtilis. "Plant Protect. Sci". 39 (2): 70-77.

Palvic, D., Wingfield, M.J., Barber, P., Slippers, B., Harder, G.E.S. and Burgess, T.I. (2008).
Seven new species of the Botryosphaeriaceae from baobab and other native trees in Western Australia. Mycologia. 100 (6): 851-6

Saeed, K. (2012). Causes of post-harvest Losses of Mango and Shea fruits in Northern Ghana, West Africa. Master's dissertation. Pp18-55.

Shri, S. Y. (2013). Post-Harvest Profile of Mango. Department of Agriculture and Cooperation, Nagpur, India, pp 5-139.

Stovold, G.E. (2004). Blight diseases in mangoes. In: DPI-489 (First edition 2004). Alstonville: NSW Centre for Tropical Horticulture. Pp 1 3

Ugese, F.D, Iyango, P.O and Swem, T.J. (2012). Mango (Mangefera indica L.) Fruit Production and Production Constrains in Gboko Local Government Area of Benue State. Publication of Nasarawa State University, Keffi 8 (1): $164-174$.

Uliwa, P. (2008). Mangoes for Middle East Market Sub Sector Quick Scan, Tanzania. Match Maker Associates.Fresh Fruits and Vegetable Sub Sector/Value Chain Analysis Tanzania. Executive Summary. Available on: http://www.ushirika.coop/index.php?option= com_content\& task $=$ view\&id $=19 \&$ Itemid $=36 \&$

Yusuf, S. A. and Salau, A. S. (2007). Forecasting Mango and CitrusProduction in Nigeria: $A$ Trend analysis. Pak. J. Bot., 40 (6): 26412644. 